\section{Human herpes virus 8 antibod- ies in HIV-positive patients in Surabaya, Indonesia}

\author{
Devi Oktafiani, ${ }^{1}$ Ni LuhAyu Megasari, ${ }^{1,3}$ \\ Elsa Fitriana, ${ }^{1}$ Nasronudin, ${ }^{2,3}$ \\ Maria Inge Lusida, ${ }^{3,4}$ Soetjipto ${ }^{2,3,5}$ \\ ${ }^{1}$ Doctoral of Medicine Program, Faculty \\ of Medicine, UniversitasAirlangga; \\ ${ }^{2}$ Universitas Airlangga Hospital, \\ Surabaya, Indonesia; ${ }^{3}$ Institute of \\ Tropical Disease; ${ }^{4}$ Department of \\ Medical Microbiology; ${ }^{5}$ Department of \\ Medical Biochemistry, Faculty of \\ Medicine, Universitas Airlangga, \\ Surabaya, Indonesia
}

\section{Abstract \\ Background: Human herpesvirus 8} (HHV-8) infection is etiologically related to Kaposi's sarcoma. Antibodies directed against HHV-8 can be detected in $80-95 \%$ of HIV-seropositive patients with KS. HHV-8 serological tests have been done in several countries in Southeast Asia such as Malaysia, and Thailand however no serological data is available in Indonesia. This study was to examine the presence of HHV8 antibodies in HIV-positive patients in Surabaya, Indonesia.

Material and methods: Ninety-one serum samples were collected from HIVpositive patients in Surabaya, Indonesia. Human immunodeficiency virus-positive serum samples were collected from 10 homosexual men, 25 intravenous drug users (IVDUs) and 56 heterosexuals. Serums were then tested for the presence of HHV-8 antibody by using sandwich ELISA (Abbexa Ltd, Cambridge, UK).

Results: The total of 91 HIV-infected were testing with antibodies to HHV-8 using enzyme-linked immunosorbent assay. Antibodies of HHV-8 were detected in 7/91 $(7.7 \%)$ of the samples. According to a gender, six men (85.7\%) and a women (14.3\%) were positive of HHV-8 antibodies. No correlation regarding the gender and age from this study. The antibodies of HHV-8 was detected among intravenous drug users (IVDUs) men 5/7 (42.8\%) and 2/7 (28.6\%) from homosexual and heterosexual, respectively.

Conclusion: This study found the presence of HHV-8 antibodies in $7.7 \%$ of patients in Surabaya, Indonesia. This finding was higher more than Southeast Asian countries. The patients with a positive result could suggest measures to prevent HHV-8 infection.

\section{Introduction}

Kaposi's sarcoma-associated herpesvirus (KSHV) is a double-stranded DNA herpesvirus belonging to the $\gamma$-herpesvirinae subfamily. Human herpesvirus 8 (HHV8 ) or Kaposi's sarcoma-associated herpesvirus (KSHV) is the etiologic agent of Kaposi sarcoma (KS). ${ }^{1}$ Kaposi's sarcoma is a tumor developed from cells on lymph nodes or in blood vessels, and can also develop in other parts of the body. ${ }^{1}$ Previous studies have shown that immunosuppression is associated with an increased risk of developing KS. Kaposi's sarcoma not only occurs during HIV-1 infection (AIDS-KS), but also in transplant recipients, elderly men of Mediterranean and Middle Eastern origin (classic KS) or in children and adult men from eastern and Central Africa (endemic KS). Kaposi's sarcoma, a tumor most notably associated with the human immunodeficiency virus (HIV) epidemic, occurs in excess among apparently healthy individuals in certain well-defined geographical regions. ${ }^{2}$ HHV-8 prevalence exhibits considerable variation in different geographic regions and populations.

The several features suggest that Kaposi Sarcoma unlike other cancers, it may not result from a transformation event that results in autonomously growing tumor cells, but represents the combined effects of a virus with angiogenic properties and local or systemic inflammation. ${ }^{3}$

HHV-8 or KSHV, the only known human herpesvirus (rhadinovirus), is the most recently discovered tumor virus. ${ }^{4}$ The genome of KSHV is a linear and the length about 165 to $170 \mathrm{~kb} .^{5}$ This virus is covered by a tegument containing protein, and closed during budding of the cell. These membranes originate from the outer envelope of the lipid membrane from various specific viral hosts and glycoproteins. ${ }^{6}$ It may also exist in a circular episomal form during latency. ${ }^{7} \mathrm{HHV}-8$ is most closely related to the gamma-herpesvirus EBV. The HHV-8 genome is an icosahedral capsid of approximately 1,200 angstroms in diameter. $^{8}$

Kaposi's sarcoma is more prevalent in immunosuppressed patients than healthy people. It often occurs in Jewish, Mediterranean, African, and Middle Eastern origins. Seroepidemiological evidence of HHV-8 infection can be used to reflect the epidemiology of Kaposi's sarcoma. ${ }^{9}$ Previous study, seropositive prevalence of HHV-8 infection in general population of USA, Northern Europe, and Asia was only around zero to five percent; this was also the case in a seroepidemiological study in Malaysia, Hong Kong, and Sri Lanka where
Correspondence: Soetjipto, Department of Medical Biochemistry, Faculty of Medicine, Universitas Airlangga Mayjen Prof. Moestopo Street, No. 47, Surabaya 60131, Indonesia.

Tel. : +62 81331340518

E-mail : soetjipto@fk.unair.ac.id; soetjipto1950@gmail.com

Key words: HHV-8 antibody, HIV-positive, Surabaya, Indonesia.

Contributions: All author contributed equally.

Conflict of interest: The authors declare no potential conflict of interest.

Funding: Financial support for this study was provided by Ministry of Research Technology and Higher Education Republic of Indonesia under Grant number 43/E/KPT/2017 and in part by a Grant-in-Aid from Dato' Sri Prof. Tahir for supporting this research through the Tahir Professorship Program, Indonesia.

Acknowledgements: Thanks to Japan Initiative for Global Research Network on Infectious Disease (J-GRID); Institute of Tropical Disease, Universitas Airlangga; Department of Clinical Virology, Kobe University, Japan.

Conference presentation: The article had been presented an international conference Infectious Diseases, Biothreats, and Military Medicine (INSBIOMM) at 2019 August 2728, Surabaya, Indonesia.

Received for publication: 17 February 2020. Accepted for publication: 1 July 2020

This work is licensed under a Creative Commons Attribution-NonCommercial 4.0 International License (CC BY-NC 4.0).

(C) Copyright: the Author(s), 2020

Licensee PAGEPress, Italy

Infectious Disease Reports 2020; 12(s1):8746 doi:10.4081/idr.2020.8746

the seroprevalence of HHV-8 was found to be around 3,7\%. ${ }^{10}$ In East Java, Indonesia, there are detected of HHV-8 antigen about $14.5 \%{ }^{11}$, but the data about seroepidemiological of HHV-8 antibodies not available. The aim of this study was to explore this omission with an examination of the presence of HHV-8 antibodies in HIV-positive patients in Surabaya, Indonesia.

\section{Materials and Methods}

This study was conducted and approved the Ethics Committee by Universitas Airlangga Hospital. A total of 91 serum samples (53 males and 38 females) were 
collected between September and October 2016 from HIV-positive patients in Universitas Airlangga Hospital, Surabaya, Indonesia. The naïve or treated with antiretroviral patients were included, adult HIV-infected (in this case 18-64 years old, and the mean age is 37 years old). There are 6 patient naïve with ARV and 85 with antiretroviral therapy. Informed consent forms were obtained from each of the subjects and personal identifiers were removed to ensure patient confidentiality. A questionnaire regarding age, gender, the possibility route of transmission information was collected. Serum samples obtained were centrifuged and stored at $80^{\circ} \mathrm{C}$ until tested. Serum samples were tested to an HHV-8 antibodies by an ELISA method (Abbexa, Cambridge, UK), according to manufacturer instructions.

\section{Results}

A total of $91 \mathrm{HIV}$-infected patients were involved in this study. The majority (93.4\%) of the patients had been treated with highly active antiretroviral therapy. The serums samples were tested from 53 males and 38 females, with a mean age of 37 years (range 18-64 years). This study showed that HHV8 antibodies found in 7 of 91 samples (7.7\%). Six men $(85.7 \%)$ and a women $(14.3 \%)$ were positive of HHV-8 antibodies. No correlation among different age group. Two of seven positive with antibodies of HHV-8 was naïve patient and five patient were used antiretroviral therapy. HHV-8 antibodies were detected in $3 / 7(42.8 \%)$ among intravenous drug users (IVDUs) men and 2/7 (28.6\%) was detected from homosexual and heterosexual orientation, respectively. The determinations of HHV-8 in HIV-positive is shown in Table 1.

\section{Discussion}

Epidemiological studies of HHV-8 infection depend on serological tests because viremia is detected in some infected people without symptoms. ${ }^{12,13}$ As a result of research conducted in Surabaya, Indonesia is an interesting comparison with other studies around the world. This research refers to a previous study that hhv 8 antigen was detected, but the case of Kaposi's Sarcoma is very rare. Serological detection of hhv-8 in this study yielded lower results than antigens detected in the same case, HIV- positive patients. Previous studies, the presence of HHV-8 antigen was detected in $14.56 \%$ of HIV-positive patients in East Java, Indonesia. ${ }^{11}$ Antibodies of
HHV-8 was detected $7.7 \%$ in Surabaya. This result was lower compared to other studies, e.g., Thailand was detected $28 \%,{ }^{14}$ Xinjiang, China $31.2 \%,{ }^{15}$ Nigeria $62 \%{ }^{16}$ and Cameroon $70 \%,{ }^{17}$ India $26.6 \% .{ }^{18}$

This result of study, $42.8 \%$ HIV-infected intravenous drug users were positive HHV-8 antibodies. Heterosexual and homosexual men were detected $28.6 \%$, respectively. Ayuthaya and colleagues' research reports that in Thailand, the presence of HHV-8 lytic antigen in $12 \%$ HIV-positive homosexual men, $16 \%$ heterosexual men, and 9\% IVDUs. ${ }^{19}$ In Western countries, KSHV seroprevalence rates ranged around $20 \%$ to $40 \%$ among homosexual men, but were very low, usually below $5 \%$ to $10 \%$, in HIV-infected intravenous drug users, women, and patients with hemophilia. Given that the rate of AIDS KS among HIVinfected homosexual men in Western countries in the 1980s was in a similar range, these initial cross-sectional studies suggested that most KSHV in HIV-infected homosexual men would eventually develop into KS. ${ }^{20,21}$ HHV-8 without KS in serum samples are detected $4 \%$ and AIDS-KS are $42.8 \%$ in Brazil ${ }^{22}$ and Germany are detected $52 \%$ and AIDS-KS are $91 \% .{ }^{23}$ In HIV-positive patients without Kaposi Sarcoma, 4\% were positive using PCR method. These patients certainly present a higher risk of developing AIDS-KS. ${ }^{20}$ In previous study, the progression of KSHV infected to KS was faster after HIV infection. ${ }^{20}$ This may be the result of primary KSHV infection in an already immunocompromised individual being more extensive and severe than in an immunocompetent person. The rapid development to KS within a few weeks after KSHV seroconversion in immunocompromised patients as a result of HIV infection or transplantation. ${ }^{20,21}$

The presence of HHV-8 infection in HIV-positive patients is possibly related to the risk of developing opportunistic diseases, including Kaposi's sarcoma (classic, AIDS-related KS, endemic and iatrogenic) and other proliferative diseases, such as primary effusion lymphoma and multicentric Castleman disease. Among immuno-competent people, only a small proportion of HHV-8 infections develop into Kaposi sarcoma. The mechanism of HHV-8 to develop into KSHV has many considerations. Some studies mention that KSHV can promote the proliferation of primary endothelial cells. Infection of endothelial cells leads to their transformation and proliferation. Invasion of the subendothelial cell layer, such as the dermis of the skin, occurs. Proliferation is mainly driven by cytokine stimulation of latently infected cells in a paracrine manner. Viral cytokines such as vIL-6, a homologue molecule of human IL-6, stimulates the production of VEGF. Viral IL-6, produced by latent and lytically infected cells, is able to stimulate the gp130 chain of the IL-6 receptor and results in modulation of gene transcription. The viral GPCR, a constitutively active homologue of the IL- 8 receptor, is expressed in lytically infected cells and also alters intracellular signaling pathways to promote cell transformation and cytokine production. The secretion of VEGF is a primary driver of endothelial cell proliferation via the VEGF receptor. Most of the proliferating cells are latently infected with $\mathrm{HHV}-8$ and develop into characteristic spindle cells. ${ }^{24}$

Various tests have detected HHV-8 antibodies in the majority of asymptomatic individuals with increased tumor risk, including HIV-positive homosexual men, ${ }^{25}$

Table 1. Determinants of HHV-8 antibodies in HIV-infected patients

$\begin{array}{lccc}\text { Characteristic } & \text { N } & \text { HHV-8 positive N (\%) } & \text { P value } \\ \text { Age group (years) } & & & \\ \text { A: } \leq 30 & 23 & 3(13.04) & \\ \text { B: } 31-40 & 39 & 2(5.1) & \text { p: } 0.6 \text { (NS) } \\ \text { C: }>40 & 29 & 2(6.9) & \\ \text { Sex } & & & \\ \quad \text { Male } & 53 & 6(11,3) & \text { p: } 0.1 \text { (NS) } \\ \quad \text { Female } & 38 & 1(2.6) & \\ \text { Sexual orientation } & & & \\ \quad \text { Homo/bisexual } & 10 & 2(20) & \\ \quad \text { Heterosexual } & 81 & 5(6.17) & \\ \text { Possibility route of HIV infection } & & & \\ \quad \text { Sex transmission } & 61 & 4(6.5) & \\ \quad \text { Sharing needles or syringes } & 25 & - & \\ \quad \text { Vertical route (mother to child) } & - & - & \\ \quad \text { Unknown } & 5 & & \end{array}$

$\mathrm{p}<0,05, \mathrm{~S}$ (Significant), NS (Not Significant). 
adults from Italy and various regions of sub-Saharan Africa ${ }^{26,27}$ and some low risk people, such as blood donors from the UK, USA, and Jamaica. ${ }^{28,29}$ Several studies using different serological tests found that almost $100 \%$ patients with different clinical forms of Kaposi's sarcoma had a high titer of the HHV-8 antibody, which had been detected before the appearance of clinical lesions of Kaposi's sarcoma. ${ }^{13,30,31}$ Current evidence suggests that HHV-8 infection is a prerequisite in the pathogenesis of Kaposi's sarcoma, but factors relating to the host immunodeficiency may greatly increase the incidence of Kaposi's sarcoma among subjects infected with HHV-8.

Antiretroviral also may have a role in the treatment of HHV-8-related disease independent of its immune-restorative properties in persons with HIV. In addition to the previously mentioned effects on $\mathrm{HHV}-8$ shedding and viremia, zidovudine and stavudine both have been shown to be competitive inhibitors of the HHV-8 thymidine kinase, ${ }^{32,33}$ and ritonavir demonstrates a strong antitumorigenic effect against KS. ${ }^{34,35}$

\section{Conclusions}

The presence of HHV-8 antibodies was found in $7.7 \%$ of the HIV-positive patients who participated in this study. Based on these results found in patients among Surabaya, further examination should be conducted on patients living with HIV. This would assist with early detection and subsequent management of any clinical manifestations related to HHV-8 infection, especially in the form of Kaposi's sarcoma lesion. The patients with a positive result could suggest measures to prevent HHV-8 infection.

\section{References}

1. Dourmishev LA, Dourmishev AL, Palmeri D, et al. Molecular genetics of Kaposi's sarcoma-associated herpesvirus (human herpesvirus 8) epidemiology and pathogenesis. Microbiol Mol Biol Rev 2003;67:175-212.

2. Beral, V. Epidemiology of Kaposi's sarcoma. Cancer Surv 1991;10:5-22

3. Schulz TF, Cesarman E. Kaposi Sarcoma-associated Herpesvirus: mechanisms of oncogenesis. Curr Opin Virol 2015;14:116-128

4. Viejo-Borbolla A, Ottinger M, Schulz TF. Human herpesvirus 8: Biology and role in the pathogenesis of Kaposi's sarcoma and other AIDS-related malignan- cies. Curr HIV/AIDS Rep 2004;5:169175.

5. Renne R, Lagunoff M, Zhong W, Ganem D. The size and conformation of Kaposi's sarcoma-associated herpesvirus (human herpesvirus 8) DNA in infected cells and virions. J Virol 1996; 70:8151-4.

6. Swaminathan, S. Molecular biology of Epstein-Barr virus and Kaposi's sarcoma-associated herpesvirus. Seminars in Hematology 2003;40:107-115.

7. Lagunoff M, Ganem D. The structure and coding organization of the genomic termini of Kaposi's sarcoma-associated herpesvirus. Virology 1997; 236:14754.

8. Trus BL, Heymann JB, Nealon K, et al. Capsid structure of Kaposi's sarcomaassociated herpesvirus, a gammaherpesvirus, compared to those of an alphaherpesvirus, herpes simplex virus type 1, and a betaherpesvirus, cytomegalovirus. J Virol 2001; 75: 2879-90.

9. Grulich A, Rawlinson WD, Cunningham P. Human herpesvirus 8: a newly described sexually transmissible infection. Venereology 2001;14:174180

10. Ablashi D, Chatlynne L, Cooper H, et al. Seroprevalence of human herpesvirus-8 (HHV-8) in countries of Southeast Asia compared to the USA, the Caribbean and Africa. Br J Cancer 1999;81:893-897.

11. Oktafiani D, Megasari NL, Fitriana E, et al. Detection of human herpesvirus 8 antigen in HIV infected patients in East Java, Indonesia. AJID 2017;12:43-46.

12. Laduca JR, Love JL, Abbott LZ, et al. Detection of human herpesvirus 8 DNA sequences in tissues and bodily fluids. $\mathrm{J}$ Infect Dis 1998;178:1610-1615.

13. Whitby D, Howard MR, TenantFlowers M, et al. Detection of Kaposi sarcoma associated herpesvirus in peripheral blood of HIV-infected individuals and progression to Kaposi's sarcoma. Lancet 1995;346:799-802.

14. Chen N, Nelson KE, Jenkins FJ, et al. Seroprevalence of Human Herpesvirus 8 Infectionin Northern Thailand. Clin Infect Dis 2004;39:1052-8.

15. Zhang T, Shao X, Chen Y, et al. Human Herpesvirus 8 Seroprevalence, China. Emerg Infect Dis 2012;18:150-152.

16. Ogoina D, Onyemelukwe G, Musa BO, Babadoko A. Seroprevalence and determinants of human herpes virus 8 infection in adult Nigerians with and without HIV-1 infection. Afr Health Sci 2011;11:158 - 162 .

17. Mbondji-Wonje C, Ragupathy V, Lee S, et al. Seroprevalence of Human Herpesvirus- 8 in HIV-1 Infected and Uninfected Individuals in Cameroon. Viruses 2013;5:2253-2259.

18. Munawwar A, Sharma K, Gupta S, Singh S. Seroprevalence and Determinants of Kaposi SarcomaAssociated Human Herpesvirus 8 in Indian HIV-Infected Males. AIDS Res Hum Retroviruses 2014;30:1192-1196.

19. Ayuthaya PIN, Katano H, Inagi R, et al. The seroprevalence of human herpesvirus 8 infection in the Thai population. Southeast Asian J Trop Med Public Health 2002;33:297-305.

20. Renwick N, Halaby T, Weverling GJ, et al. Seroconversion for Kaposi's sarcoma-associated herpesvirus is highly predictive of KS development in HIV-1 infected individuals. AIDS 1998;12:2481-2488.

21. Jacobson LP, Yamashita TE, Detels R, et al. Impact of potent antiretroviral therapy on the incidence of Kaposi's sarcoma and non-Hodgkin's lymphomas among HIV-1- infected individuals. Multicenter AIDS Cohort Study. J Acquir Immune Defic Syndr 1999;21:S34-41.

22. Machado I, Farias K, Pereira M, et al. Human herpesvirus 8 (HHV-8) detected by nested polymerase chain reaction (PCR) in HIV patients with or without Kaposi's sarcoma. An analytic crosssectional study. Sao Paulo Med J 2015;134:187-192.

23. Albrecht D, Meyer T, Lorenzen T, et al. Epidemiology of HHV-8 infection in HIV-positive patients with and without Kaposi sarcoma: diagnostic relevance of serology and PCR. J Clin Virol 2004;30:145-149.

24. Anonym; 2013. Available from: www.immunopaedia.org. Accessed : March 2017.

25. Martin JN, Ganem DE, Osmond DH, et al. Sexual transmission and the natural history of human herpesvirus 8 infection. N Engl J Med 1998;338:948-954.

26. Sitas F, Carrara H, Beral V, et al. Antibodies against human herpesvirus 8 in black South African patients with cancer. N Engl J Med 1999;340:18631871.

27. Calabro ML, Sheldon J, Favero A, et al. Seroprevalence of Kaposi's sarcomaassociated herpesvirus/human herpesvirus 8 in several regions of Italy. J Hum Virol 1998;1: 207-213

28. Simpson GR, Schulz TF, Whitby D, et al. Prevalence of Kaposi's sarcoma associated herpesvirus infection measured by antibodies to recombinant capsid protein and latent immunofluores- 
cence antigen. Lancet 1996;349:11331138 .

29. Engels EA, Eastman H, Ablashi DV, et al. Risk of transfusion-associated transmission of human herpesvirus 8 . J Natl Cancer Inst 1999;91:1773-1775.

30. Gao SJ, Kingsley L, Li M, et al. KSHV antibodies among Americans, Italians and Ugandans with and without Kaposi's sarcoma. Nat Med 1996;2: 925-928.

31. Moore PS, Kingsley LA, Holmberg SD, et al. Kaposi's sarcoma-associated her- pesvirus infection prior to onset of Kaposi's sarcoma. AIDS 1996;10:175180.

32. Gustafson EA, Schinazi RF, Fingeroth JD. Human herpesvirus 8 open reading frame 21 is a thymidine and thymidylate kinase of narrow substrate specificity that efficiently phosphorylates zidovudine but not ganciclovir. J Virol 2000; 74:684-92.

33. Lock MJ, Thorley N, Teo J, Emery VC. Azidodeoxythymidine and didehydrodeoxythymidine as inhibitors and substrates of the human herpesvirus 8 thymidine kinase. J Antimicrob Chemother 2002; 49:359-66.

34. Pati S, Pelser CB, Dufraine J, et al. Antitumorigenic effects of HIV protease inhibitor ritonavir: inhibition of Kaposi sarcoma. Blood 2002; 99:37719.

35. Sgadari C, Barillari G, Toschi E, et al. HIV protease inhibitors are potent antiangiogenic molecules and promote regression of Kaposi sarcoma. Nat Med 2002; 8:225-32. 